\title{
एव| Ethnologia
}

Anne Eriksen 2021: The Intrusiveness of Heritage: The Vikingification of a Small Community in Vestfold, Norway. Ethnologia Europaea 51(2): 1-22. DOI: https://doi.org/10.16995/ee.2955

\section{ब(1) \\ Open Library of Humanities}

\section{The Intrusiveness of Heritage}

\section{The Vikingification of a Small Community in Vestfold, Norway}

Anne Eriksen, University of Oslo, Norway, anne.eriksen@ikos.uib.no

\begin{abstract}
While heritage is almost by definition understood as fragile, vulnerable and in need of protection, this article argues that it is also a powerful cultural force in contemporary society. The small community of Borre, south of Oslo in Norway, is used as a case to investigate how heritage has the power to invade and colonise, and how it has the capacity to create new meanings and redefine social relations. A triad of concepts - expansion, intensification and entanglement - is proposed as a tool for investigating these processes. The article argues that heritage processes "devour" the local culture, turning sites, activities and objects into a Viking mode and becoming a dominant key of understanding.
\end{abstract}




\section{The Paradoxes of Heritage and Heritage Making}

Heritage is fraught with paradoxes. Created by processes that take place in the present, its fascination nonetheless rests on the denial of its being a fabrication and its promise to provide firm and essential grounding for sociocultural identities (Meyer \& Van de Port 2018). Despite the great importance of discursive practices when it comes to the creation and enjoyment of heritage (Smith 2006), its material aspects cannot be ignored. As the living traditions of living people, or as material traces from the past, heritage has a strong physical presence. This presence includes the materiality of institutions and experts for heritage care and management.

In this article, I will investigate what happens in cases where heritage starts to grow, expand and more or less colonise an entire local community. I argue that this development is accompanied by processes of intensification and entanglement, and I investigate how these processes contribute to a transformation of the landscape. Through these transformations, new values, considerations and obligations are imposed on the local community. My questions are: what tensions, disputes and discussions do these transformations produce? There are of course no simple answers to such questions, and what actually occurs will vary from case to case. The aim of this article is nonetheless to use one empirical case to explore more general processes and to propose some analytical approaches to heritage as an "invasive power".

My general point of departure is the constructivist approach that is common to much contemporary heritage theory. More particularly I make use of perspectives that focus on heritage not only as something that is largely created in the present, but as a specific form of expressive culture with its own conventions and forms, and its own "aesthetics of persuasion" (Kirshenblatt-Gimblett 1998; Hafstein 2009; Meyer \& Van de Port 2018). This approach implies that rather than deconstructing "authorised heritage discourse" (AHD), which is a major issue in critical heritage studies, I emphasise instead the innovative aspects of heritage work, and the transformative effects that follow from it. Such perspectives are important because critical approaches that successfully identify the constructed nature of heritage generally fail to explain why these constructions continue to work, and how heritage can go on to become such a powerful social force. Recent research consequently has called for approaches that go beyond critical deconstruction and that look further than representations alone (Waterton 2019; Meyer \& Van de Port 2018). Inspired by such perspectives, the present article will examine the production of heritage in a small community in order to understand how heritage can work as a cultural force with the power to appropriate, redefine and take possession of local meaning-making and social relations. 
Empirically, this study stems from an ongoing project at Borre in Vestfold and Telemark County, south of Oslo and close to the Oslo fjord (see also Eriksen 2019). For three successive summer seasons I have explored heritage work and production in this community, making numerous visits to the site, observing other visitors and participating in such heritage events as markets and festivals (Author's fieldwork notebook). I have also conducted interviews with heritage professionals at the site. This fieldwork has continually been supplemented by explorations of relevant websites and local news media, most notably the local newspaper Gjengangeren; the websites of the heritage experience centre, Midgard Vikingcenter and the local Viking association, Borre Vikinglag. I did not have the opportunity to participate in person in the pilgrimage that introduces the next section of the article, but have followed the expansion of the heritage field at Borre both before and after the new pilgrim path was inaugurated. My approach has involved focusing on both the work of professionals and the activities and meaning-making of visitors and locals. The aim of the following case study is not to present a comprehensive investigation of the heritage work that takes place at Borre, but to use the material that has been collected within the project as a site for the unpacking of concepts and approaches.

\section{When Pilgrims Visit Vikings - the Heritage Field}

In May 2019, a new pilgrim path was inaugurated in Vestfold and Telemark County. Starting from the cathedral in Tønsberg, pilgrims walked for about three hours to the small community of Borre. Services were held in Borre medieval church, but upon arrival the pilgrims first visited the large field of the Viking Age burial mounds that is situated between the church and the ocean. The next day's programme started with a visit to Midgard Vikingcenter, just outside this ancient burial field.

Why do pilgrims visit Vikings? Why is a Viking experience centre included in a pilgrimage? The Viking Age, from the late eighth to the early eleventh century was the latter part of the pre-Christian era in the northern European countries. Even if Vikings through their raids brought with them knowledge about the new Christian religion, Vikings are mostly associated with a fierce and violent pagan culture. They do not only belong to a different historical epoch, but also represent values and ethics that are the very antithesis of those held by Christian pilgrims. Nonetheless, these two worlds are brought together at Borre, both integral elements of the newly created path.

The path was part of the national pilgrim initiative Saint Olav Ways - the Pilgrim Paths to Trondheim, named after Norway's patron saint and supported by the Norwegian (Lutheran) Church as well as by tourist and heritage associations. Its website presents the attractions of this part of the walk: 
Tunsberg-leden [ = the path] goes through the town centre of Tønsberg along Storgaten, a street that has been in use since the Viking Age. From Slottsfjellet and Frodeåsen there are many viewpoints. In Åsgårdstrand you can visit the house of the famous artist Edvard Munch and spend the night at the Grand Hotel Åsgårdstrand, paying a pilgrim price. If you want to continue to Borre, the pilgrim path follows the coast in a beautiful nature reserve. At Borre lies a medieval church and between the church and the fjord you'll find the world's largest collection of large burial mounds from the Viking Age, the Midgard Viking Centre and the Guild Hall. There are accommodation possibilities near the Guild Hall on RS Noatun and at Thon Hotel Horten in the city centre near the ferry terminal. The ferry to Moss provides a connection to trains, and to Borg-leden on the east side of the fjord (Pilegrimsleden, English original).

Enhanced by an image of the majestic mounds at Borre, the text makes it clear that pilgrims and Vikings (as well as the twentieth-century painter Edvard Munch and some natural scenery) belong to the same context: the heritage field (see fig. 1).

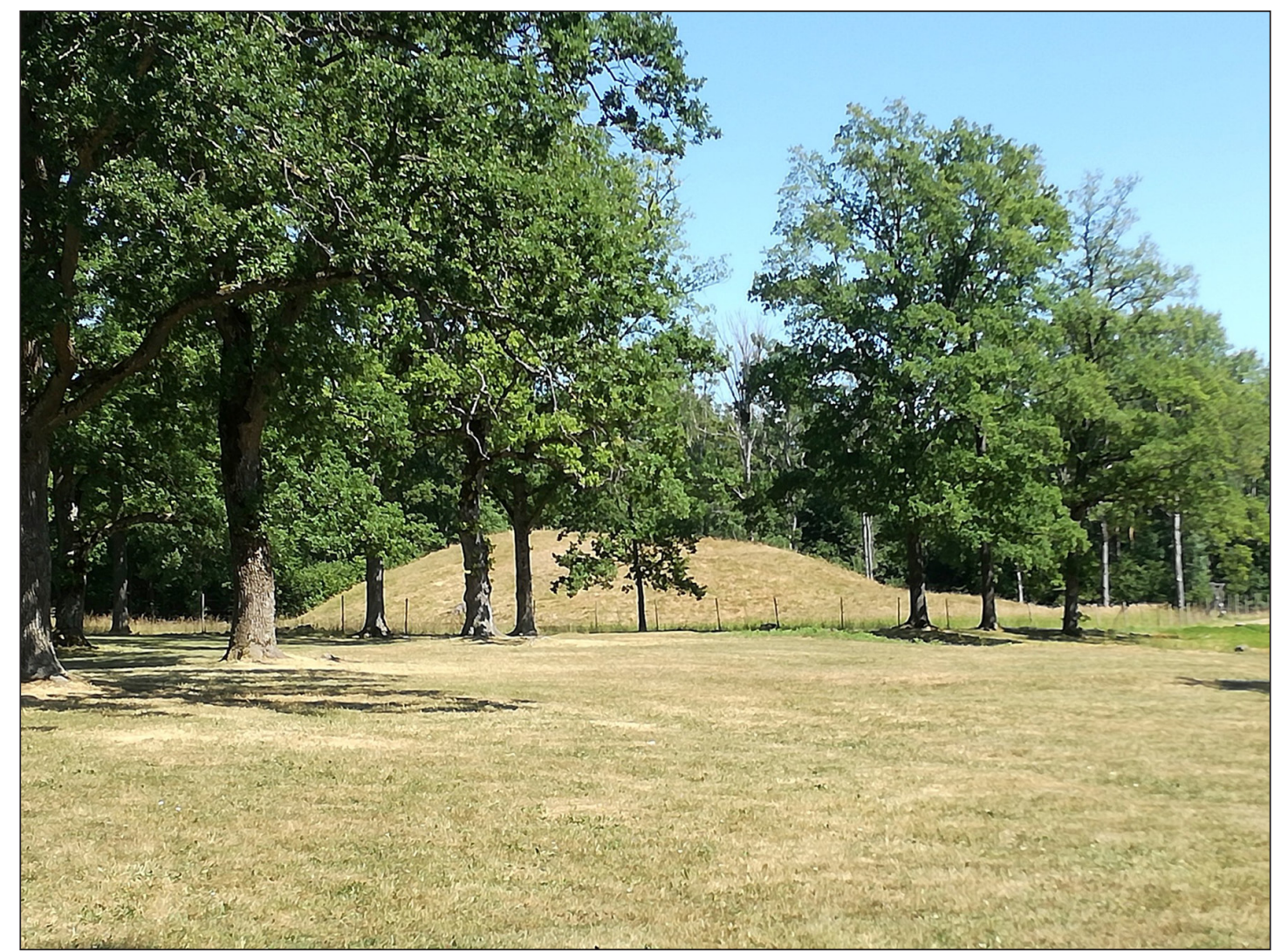

Figure 1: One of the mounds at Borre. (Photo: Anne Eriksen, 2019). 
The capacity to conflate different historical epochs by mapping them on to the same locality is one of the paradoxes of heritage. Heritage sites are able to create a special kind of synchronicity or apparent contemporaneity between different periods and objects (Renes 2015: 415). As Sharon Macdonald has argued about local museums, they conflate place with community, which in turn implies that "to be of the place" as she terms it, means to belong to the community (Macdonald 2013: 154). Objects that share this quality of belonging acquire a local identity independent of their original and diverse provenance or context (Macdonald 2013: 154-155). Her argument illustrates the cultural energy that is intrinsic to heritage, and its power of (re-)definition and appropriation. To examine these mechanisms at Borre, I will use three key concepts - expansion, intensification and entanglement - which are also proposed as analytical tools for an understanding of heritage as a special kind of cultural production. At a higher level, they represent an approach to what can be termed heritage rationality: the logic of the past when it is given the name of heritage and set to work in the present.

Approaching my empirical case, it is important to point out that in contrast to many heritage stories, this is not one of disputes or conflicts. Nobody wants to do away with the mounds, the Viking experience centre, the church or anything else within the heritage field at Borre. The opposite is the case. The locals enjoy the area's natural beauty with its beach, fjord and mounds among large trees situated in an idyllic rural landscape. Great pride is also invested in the heritage site because it places the small community of Borre firmly in national history (Myhre \& Gansum 2003; Gansum \& Østigård 2009; Guttormsen 2014). Archaeologists of the early twentieth century did not hesitate to identify the majestic mounds as the graves of ninth-century King Harald Fairhair's forefathers, the king who is celebrated for founding the first unified kingdom of Norway (Brøgger 1916). Harald supposedly descended from the mythical Ynglinge dynasty, and according to the thirteenth-century saga of Snorri Sturluson, his ancestors were buried at Borre. Bearing this in mind, Borre has been ascribed a significant role as cradle of the ancient Norwegian kingdom by the influential professor of archaeology A.W. Brøgger. ${ }^{1}$ The majority of Viking ships that have been found in Norway come from this region, and Borre's proximity to the monumental Viking burials at Oseberg and Gogstad has lent important support to its role. On the initiative of Brøgger and the industrial magnate Sam Eyde, the field of burial mounds at Borre was inaugurated as a National Park in 1932 (Eriksen 2019). In his speech at the opening ceremony, addressing King Haakon VII and an audience of about 6,000 people, Brøgger strongly emphasised the role of

\footnotetext{
1 Modern archaeological excavations were carried out at Borre from 1988 to 1992, led by Professor Bjørn Myhre. The project produced more nuanced knowledge, but no new discoveries of ships or other large material remains were made (Myhre 2015).
} 
Borre as a monument to the Norwegian nation state, calling the new park "the garden of the realm" (Brøgger 1932: 4).

The site continues to be an important part of Norway's national heritage, even though archaeological theory has changed and recent research indicates that important parts of the mounds and settlement at Borre are older than the Viking Age (Myhre 2003). The connections to the Ynglinge dynasty have also been strongly questioned (Krag 1991). Borre's links to the Vikings nonetheless remain strong among heritage professionals as well as the general public. Proposed as a World Heritage site together with other Viking Age traces in the region, the burial field has entered international heritage discourse, while the local inhabitants for their part are still very proud of "their" own Vikings and monuments (Unesco, Tentative Lists).

"Heritage field" is a term that can be understood literally as a physical location. At Borre this field is made up of the mounds, the experience centre, the church and the old vicarage. This constitutes an area reaching from the beach up to the main road. The rest of the community is largely residential, which means that most of the places where people can meet locally are situated within the heritage field. The beach, the small-craft harbour, the park and the surrounding woods are all very popular among the locals. The people who live in Borre have to deal with heritage, even if they are not particularly interested in history.

However, the heritage field can also be understood discursively as a specific way of talking about things, framing them as heritage. This is very much about ascribing value and turning things - material or immaterial - into something special, thus giving them a "second life as heritage", as Barbara Kirshenblatt-Gimblett has put it (1998: 129). Processes of this kind are often argued to set heritage apart from normal everyday life, turning it into something special, cherished and in need of special care and protection (Hafstein 2009). Such processes establish an "authorised heritage discourse" (Smith 2006; Smith [ed.] 2006; Smith \& Waterton 2009; Smith 2015). This has obviously also taken place at Borre, with large parts of the area protected by national heritage law. What will be explored in this analysis, however, is not processes of separation, but rather the mix of connections and concurrences that are present, and which, I argue, are intrinsic to heritage production and creativity, at times leading to tensions and conflicts.

At Borre, the discursive heritage field largely overlaps with the physical one, meaning that large parts of the community are spoken of in heritage terms, and, for that matter, are protected by heritage laws. The heritage field nonetheless also remains part of everyday life. The area is actively used and highly popular for such mundane activities as outings, rambles, exercise and walking dogs. 


\section{Expansion}

The heritage field at Borre is expanding. Its area and dominance are growing. This relates both to the physical and the discursive field. The first major expansion was the experience centre, Midgard Vikingcenter, which opened in 2000, and is situated west of the original park. The building was designed by a leading architectural company in Norway, Lund \& Slaatto, which is well known for their explicitly modernist style (Lund \& Slaatto Architects). The location at some distance from the park and the mounds was deliberately chosen to avoid erecting a modern building on ground that might have archaeologically relevant material underneath it. In 2007, traces of four large ancient halls were discovered in a grain field between the park and the Midgard Vikingcenter. When a large so-called Guild Hall was erected north of the centre in 2013, the archaeologists in charge were emphatic that this new building was not to be understood as a reconstruction or copy of what had been found (see fig. 2). Instead, it has been called a "statement" and an "argument" in the ongoing scholarly debates over Viking Age buildings (Interview Gansum, 6 July 2018). It can also be related to trends in experimental archaeology (Flores \& Paardekooper 2014). The Guild Hall has nonetheless become an important "Viking attraction". Visitors to the experience centre tend to be more interested in seeing the hall than in exploring the area where the mounds are located (Author's fieldwork notebook, 30 July 2020). The hall can also be rented for parties and events, and serves to broaden the educational outreach of the Midgard Vikingcenter.

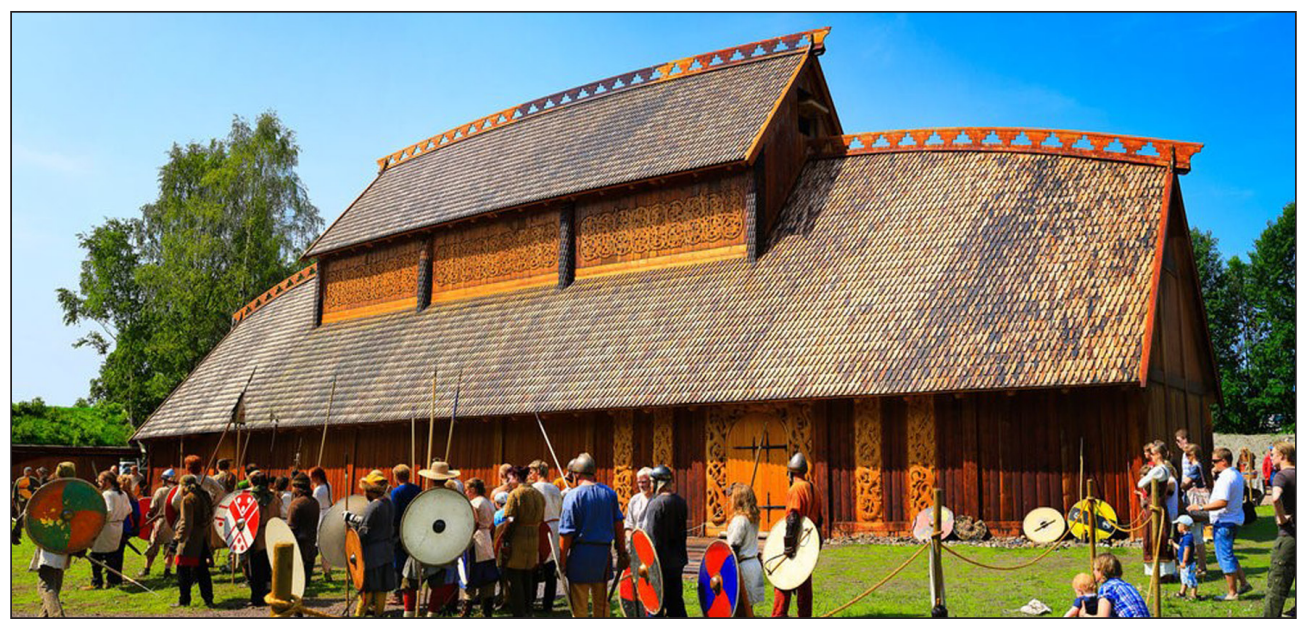

Figure 2: The Guild Hall during the Viking festival in July 2019. (Photo: Søren Ubisch).

An important point in the present context is that neither of these buildings - the centre or the hall - are heritage in the sense of old or authentic, but they very effectively contribute to enlarging the heritage field at Borre. This field has grown because the new 
buildings add the area between the mounds and the road to the existing field. This new area is internally connected by footpaths through the woods, which are well-marked with signposts pointing towards the hall, the mounds and the centre, thus spelling out the connections between them. The space between the centre and the park is called the "Viking playground" (Midgard Vikingcenter). It is used for Viking games and sports as well as for the demonstration of crafts and other Viking activities, largely aimed at children and visiting school classes. The area between the centre and the hall is the venue for a bi-annual Viking festival in July, and for an annual heavy-metal festival, Midgardsblot, in August. The audiences for such events enter by way of the Midgard building and proceed towards the Guild Hall, around which the activities are centred.

Other expansive elements are less well defined in terms of historical connection to the mounds. Situated at the different peripheries of the (already expanded) heritage field, they nonetheless signal what may be the next stages in the ongoing development. During the summer of 2018, the roundabout at the junction between the main road and the entrance to the village behind the Midgard building, was decorated with four Viking heads, each of them 1.2 metres high and carved in oak by a local artist. The work was carried out at Midgard, and was proudly presented in the local newspaper as "Viking art" (Gjengangeren 12 July 2018). The roundabout extends the heritage field northwards. Situated at the junction of the main road and entrance to the town it also attaches the local community and its Viking heritage (see fig. 3).

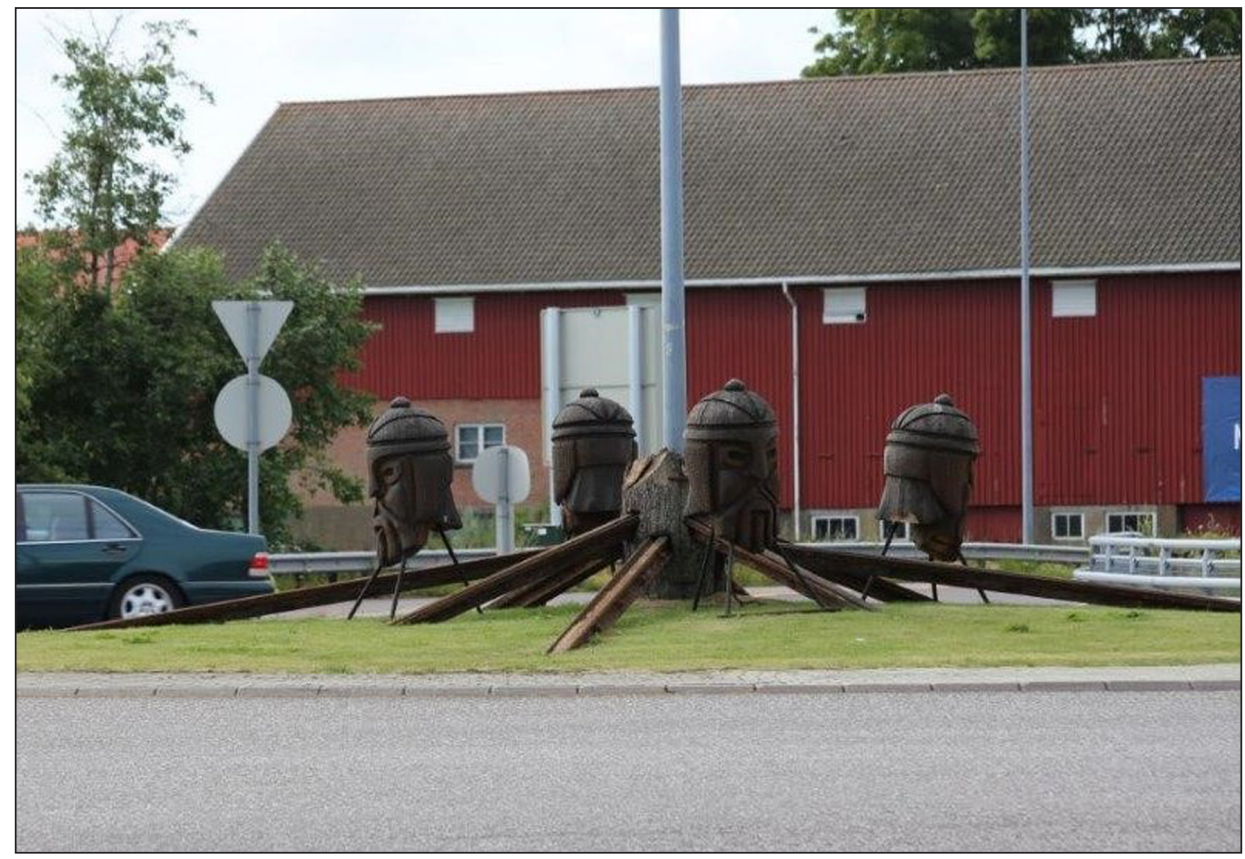

Figure 3: The Viking roundabout, summer of 2019. (Photo: Søren Ubisch). 
On the seafront, archaeological investigations have discovered traces of a prehistoric harbour and bridge. To the practised eye, some of the traces are observable from the landscape, while others can be discerned only by means of advanced digital technology (Interview Gansum, 13 August 2019). Most of the area, largely a low and sandy bay, is part of the public beach. The area is popular for bathing and excursions. It is also crossed by a coastal track that is much used by walkers and joggers. If this part of the beach were to be included in the archaeological park, the popular track would be cut off and the public beach area significantly reduced. While this reduction of the freely accessible area probably would not be well received locally, politicians speak enthusiastically about "developing a new Viking harbour" at Borre (Tønsbergs Blad 23 April 2015). This harbour, however, would not be identical to the one discovered by archaeologists. The ancient harbour would be protected by heritage law, and the possibilities for modern use restricted. The new harbour, existing so far only in discourse, would be intended as an attraction for visitors, offering activities and experiences. Both the ancient and proposed new harbours would expand the existing heritage field.

South of the newly discovered ancient port there is a modern small-craft harbour called Steinbrygga - the Stone Bridge - with a slipway and crane. At Borre, virtually everyone has a boat, or at least has a neighbour or a friend with one, and the harbour is crowded with local and visiting boats all through the summer. The wide bridges, formed as a square, are used for sunbathing, hobby fishing and picnics, and are a highly cherished social meeting place. The entire construction was built by local voluntary work just after the Second World War. Each person who participated in the work then earned the right to keep a boat in the new harbour. These berths cannot be sold, but may be passed on through inheritance, which means that the same families may have held the same berths for decades. If the berths become vacant, they are redistributed by the boating association according to a waiting list where people not living in the community are only very rarely considered (Steinbrygga). This system has kept the port strictly local and totally uncommercial, and also made it the most important meeting place in the community.

The heritage field has not been extended to the harbour - yet. But there clearly is a potential impulse to do so. The web page of the boating association shows discursive heritage processes in the making:

Steinbrygga - the harbour of the Vikings?

The port has a long history, let us present some of it. Go far back in time for a moment: Was this the place where our ancestors the Vikings had their harbour? One 
thing we know for sure is that for several hundred years and until quite recently the stone bridge was the dock for people coming to church from the fjord. (Steinbrygga, author's translation)

The accompanying image is a recent photo showing people hauling a wooden boat that looks like a small Viking craft, completely different compared to the leisure crafts that are kept in the harbour today. The image does not depict the normal, presentday activities in the harbour, but together with the text it is easily interpreted as an indication that the port is on its way to becoming heritage, representing another extension of the heritage field.

References to Vikings are, however, not the only cultural resources that may be evoked to achieve such a transformation of the modern harbour. The bridges were built from rocks which were cleared from the fields above the beach after the Second World War. For military reasons, Borre had a massive German presence during the war. This is where the Oslo fjord narrows, making the strait outside Borre the gateway to Oslo. Large rocks from a nearby quarry had been placed on the sloping fields to protect German gun positions and prevent an allied invasion from the sea. Today, there is a keen amateur interest in local history of the area (Borre historielag). The story about the locals who celebrated the end of the war by clearing the defeated enemy's defensive barriers and using them to make a harbour for themselves may prove to supply material for new heritage production.

Including a small-craft harbour in a heritage field to protect the field of burial mounds may seem somewhat far-fetched. An experience centre may also appear a more likely way of expanding the existing heritage field than decorating a roundabout. Nonetheless, all these activities are part of the same process. The heritage field has expanded, physically as well as discursively, which means that more elements and a larger area are treated and spoken of as heritage, and thus the number of actors in the field also grows. Among them are active heritage entrepreneurs and professionals who advocate for expansion, for instance by attempting to extend the area that is protected by the Norwegian heritage act. Equally important to an understanding of these processes, however, is the fact that not everybody is explicitly interested in history or particularly knowledgeable about the Vikings. The activities in which they engage are those of their local community and do not always differ significantly from those of everyday life. The roundabout is a regular part of the local transportation system, independent of its Viking adornments. The small-craft harbour and popular beaches are still used as such 
despite their Viking associations. In the case of Borre, heritage is not separated from everyday life, but represents an added value and is capable of incorporating a growing number of people, activities and engagement.

\section{Intensification}

Expansion of the heritage field is not the only process occurring at Borre, however. Processes of intensification are equally important to the social forces of heritage. Intensification here refers to the process by which the meaning ascribed to the heritage field becomes denser, and an increasing number of elements are activated to emphasise it. The church at Borre is an example of this development. This is a building from the early twelfth century, and as such it is protected by heritage law. It has been the local parish church since ancient times and is in regular use by the congregation. The graves in the churchyard carry the family names of local sailors, merchants and farmers. It also holds a small mausoleum erected by the industrial magnate Sam Eyde (1886-1940) to house his own grave. Integrating the church into a national pilgrimage route and referring to it as a pilgrims' church have not altered it materially but have added new layers of meaning to it, increasing its heritage density. The church is closely connected to the local congregation, but as one stop on a pilgrim route, it is also connected to other churches along the same route as part of the national Saint Olav Ways network. This process makes the church less local and more universal. Moreover, the church has become part of the modern international phenomenon of pilgrimage "reframed" in terms of heritage (Bowman, Johannsen \& Ohrvik 2020: 439). This does not preclude its regular use by the parish, but adds meaning that lifts the church out of its immediate surroundings and situates it in new contexts.

Obviously, the Midgard Vikingcenter, the new Guild Hall and the decorated roundabout all contribute to this process of intensification. Using a term borrowed from Erwin Goffman, they all work as framing devices, which means that they define and spell out exactly how the park with the mounds - and to some extent the entire community - are understood, and what their significance is (Goffman 1974). According to Iwona Irwin-Zarecka, who has applied Goffman's perspective to the study of cultural memory, "the function of such devices is not to 'freeze' one particular reading as the correct one; rather, it is to establish the range of meanings" (Irwin-Zarecka 1994: 4).

While they all share the function mentioned by Irwin-Zarecka, the framing devices identified at Borre achieve their results by slightly different means. 
The roundabout marks the entrance to the village, and can thus be seen as defining Borre in its totality as a kind of Viking world. Through its exhibitions and educational programmes, the Midgard Vikingcenter presents knowledge about the Viking Age and Viking culture, mostly based on recent archaeological research. The museum shop offers a wide selection of Viking souvenirs, ranging from memory sticks and tote bags to Viking jewellery and sheep skins. Wooden "Viking swords" and shields seem to be the most popular items in the selection, constantly drawing the attention of children who enter with their families to buy tickets to the site (Author's fieldwork notebook, 30 July 2020). In the playground outside the hall, the visitors may experience Viking games in direct and physical ways. The Guild Hall gives access to a presumably authentic Viking interior, complete with an open fire in the middle of the floor. When the hall is rented for parties, Viking food and drinks can be served. As these examples show, sensory means are important for intensification processes. Understanding them requires one to look beyond mere representations like exhibitions, information boards and pamphlets, and also beyond the intention of the heritage professionals that produce them (Waterton \& Watson 2014). Intensification is very much about the five senses and affect, about meanings that are embedded in the physical surroundings and embodied by visitors and users. Consequently, it is about appropriation and lived experience, not only about messages and knowledge that are explicitly communicated.

Intensification also takes place because the sheer number of heritage elements within the field is increasing. In March 2019, the Norwegian Minister of the Environment solemnly announced that the traces of a so far unknown Viking ship had been discovered in the park. The international importance of the finding could hardly be exaggerated, he declared at the press conference arranged to announce the discovery (Aftenposten 26 March 2019). The ship was found in a flat area of the park, close to the largest mounds and a path leading towards the sea. So far, no excavation has been initiated, and it is still unknown how much of the ship actually remains. During the summer of 2019, its placement was marked with yellow tape on the ground (see fig. 4). Even in this relatively invisible state, however, the ship served to intensify the meaning of the park by encouraging speculation about the ship and - even more excitedly - about other Viking treasures that might be hidden underground. The yellow tape represented new scientific knowledge, but above all it invited imagination, speculation and dreams. 


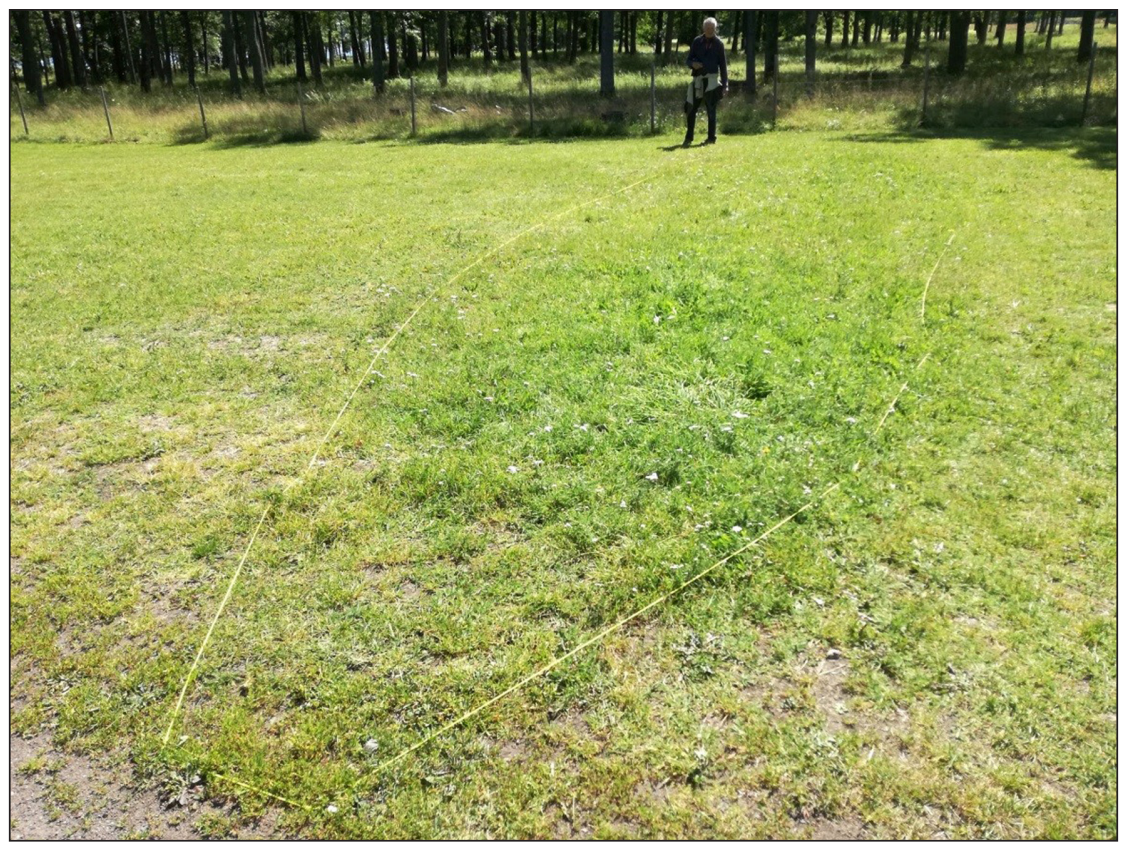

Figure 4: The newly discovered ship marked with yellow tape, summer of 2019. (Photo: Anne Eriksen).

While the intensifying effect of a "new" Viking ship is hardly surprising, other elements also contribute to charging the field with heritage meaning. In the ground just a few metres west of one of the highest mounds, the remains of a row of concrete blocks can be seen. They are the vestiges of a platform erected by the Norwegian Nazi party, which held annual rallies in the park from 1935 to 1944 . The party ideology drew heavily on old Norse history, and the rallies at Borre and other historic sites were highly encouraged by the party leadership (Myhre 1995; Winther 2019). Speaking from the platform, the party leader Vidkun Quisling explicitly placed himself in a direct line from the early kings (supposedly) buried at Borre. As part of the condemnation of the party and prosecution of its members and activities after the liberation of Norway in 1945, traces of its rallies were largely obliterated. Lately, however, the bases of the blocks on which the platform stood have been dug from the ground at Borre and are now protected by heritage law. The argument is that even dark memories are part of heritage, and that the Nazi engagement with the past can teach a lesson about politically motivated abuses of history (Interview Gansum, 6 July 2018). This message has recently been supplemented by an exhibition at the experience centre. With the title Dark Clouds at Borre, it tells the story about the Nazi ideology and rallies (Midgard Vikingcenter). The argument is emphatically cautionary, but the blocks in the ground nonetheless contribute to intensifying the meaning of the heritage field. They point explicitly to the symbolic potential and the ways in which the power of the past can be used. 
Borre is a lush area that can easily look overgrown if bushes and grass are not kept under control. To do so, a flock of sheep has been supplied by a local farmer. They graze among the trees in the middle of the park, in an area that has been fenced in. The sheep are of a traditional Norwegian breed, some of them with heavy antlers. It is strongly marketed at Borre that the animals are "Viking sheep" - implicitly the same breed that once grazed in the area. The sheep skins that are sold as souvenirs in the museum shop, are explicitly marked as "Viking". They are also used for cushions and upholstery in the Guild Hall. The sheep, and the uses to which they are put, turn heritage into nature and nature into heritage. The message conveyed is that the "same" animals have "always" grazed among the trees at Borre, which in turn implies that the trees and the greenery that can be experienced in the park have also "always" been there.

In sum, intensification is about emphasising meaning and increasing cultural value. Enhanced meanings can be conveyed as knowledge and information, but affect, sensory impression and lived experience are often just as important. Intensification processes also mean that heritage gains in significance at the cost of other possible interpretations. Heritage aspects become dominant in practice and speech, even if other more regular functions may still be maintained, as was the case with both the parish church and the grazing sheep. The meanings of the place become denser and are more univocally themed as heritage, while the plurality of other possible meanings is reduced. Expansion and intensification are reciprocally enhancing processes, often accompanying each other. On the one hand, intensification follows expansion as a means of legitimisation: The meaning and value of the extended area are emphasised and spelled out. This will often be the work of dedicated heritage professionals and is expressed in educational programmes as well as on information boards. The extended area is supplied with signposts and boards that underscore and confirm the area's identity and value as heritage. Tourist guides and teachers with school classes do the same. On the other hand, and often less driven by purposeful agents, intensification can also lead the way for further expansion. It supplies signs, words and symbols that can be used to ascribe meaning and value even to objects or phenomena outside the established heritage area.

\section{Entanglement}

The third dimension to be explored is entanglement. Entanglements involve people and practices of different kinds that have different aims. The term refers to different types of authority put in play. It includes what Siân Jones terms "social values of heritage" as well as the (supposedly) intrinsic values that usually dominate scientific and 
professional heritage discourse (Jones 2017: 22), but may also involve requirements of a more practical kind. To start with an obvious example, the traces of the abovementioned ancient hall buildings were found in a grain field owned by the vicarage and in regular use. They therefore cannot be physically included in the heritage field, and the possibilities for excavation are restricted. Archaeologists would like to explore the area more systematically, but the agricultural use of the land sets severe limitations. The field simply cannot be used for grain and excavation at the same time; it is a matter of one or the other.

The church is a simpler case to solve, for the building can easily be both a church for pilgrims and a local parish church at the same time (see fig. 5). Heritage in the guise of pilgrims represents an added value rather than a problem. Thus far also the beach, the coastal path and the harbour are popular places for excursions, bathing and boating while at the same time being the site of the ancient Viking harbour. Their entanglements do not create conflicts, even if their heritage potentiality situates them in a kind of liminal state. They belong both to the world of heritage and to that of everyday life. A separation between the two spheres cannot easily be achieved, but neither is it strictly necessary. Within local contexts, heritage and everyday life can live side by side in peaceful entanglements for long periods of time.

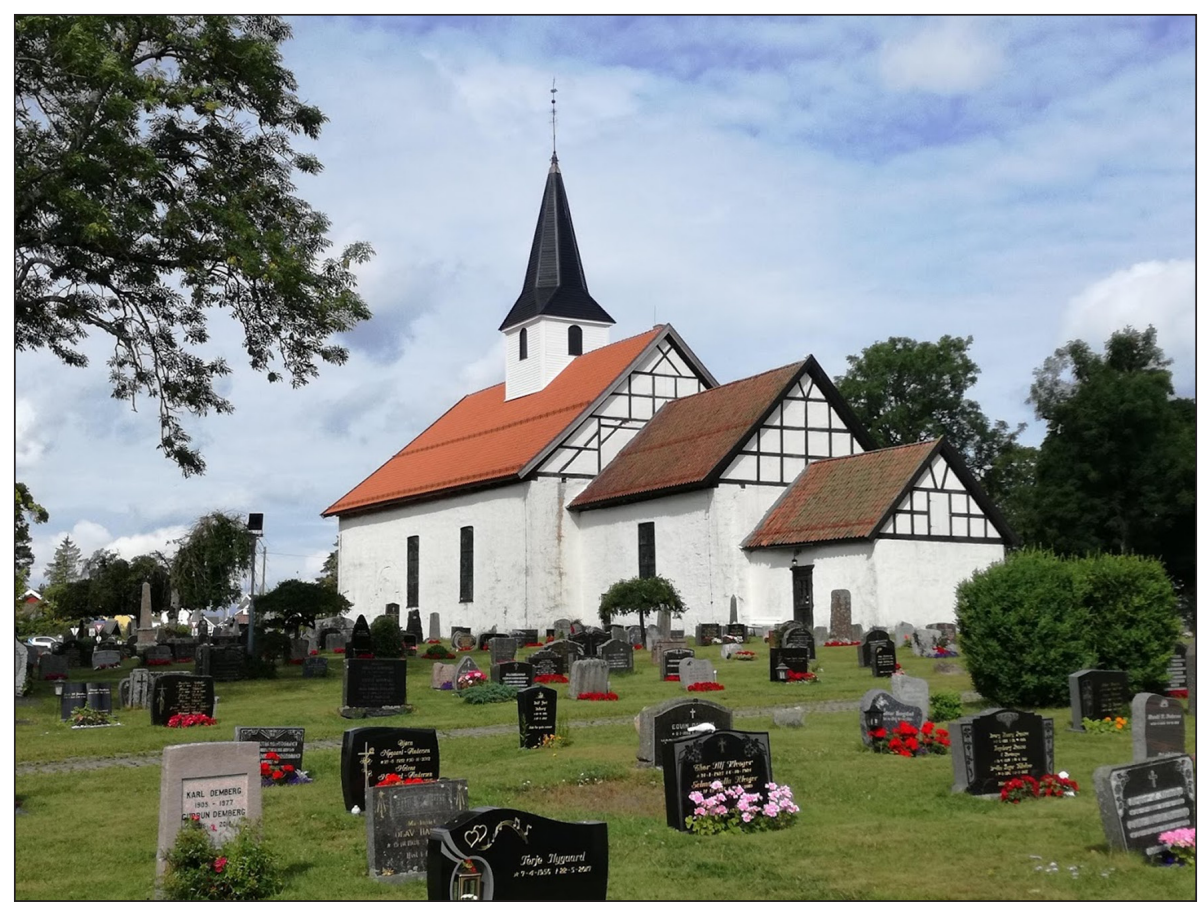

Figure 5: The church that serves both pilgrims and the parish. (Photo: Anne Eriksen, 2019). 
Borre's Nazi heritage is trickier. The traces of the platform are situated within the walls of the park, which places them at the very centre of the heritage field. As mentioned above, the message conveyed by the professionals at the Midgard Vikingcenter when it comes to these traces is emphatically cautionary. The region has a very active Viking association engaged in Viking crafts and culture and responsible for the bi-annual Viking market. Its members also volunteer for events at the Midgard Vikingcenter. Distancing themselves from Nazi and right-wing ideology is equally important to them (Borre Vikinglag).

Some years ago, however, a neo-Nazi group took an interest in the park and held ceremonies there. The municipality reacted, the police were involved and the group was banned from the park (Gjengangeren 21 August 2012). This group defines itself explicitly as heir to older Nazi ideology, and, like its self-declared predecessor, uses Viking symbols to promote right-wing nationalism. Despite this relationship, which is claimed by members of the group and acknowledged by local and national authorities, they are not recognised as a legitimate heritage stakeholder at Borre. The point here is not to argue their case, but to point out that entanglements can also cause real conflicts.

Even if less politically loaded, tensions also arose from the presentation of a new preservation plan for the park developed in 2006 (Helhetsplan for Borreparken 20072015). Two issues attracted attention. Since its inauguration in 1932, the park had been known as a "national park". From the 1970s, however, this term has been reserved for natural conservation areas in Norway. Accordingly, the plan proposed a change of designation for Borre from national park to the more correct Borreparken (the park at Borre). This was not well received locally. The change was met with a storm of protest letters to the local newspaper. The authorities were accused of lacking historical knowledge and of making arbitrary decisions. According to one local inhabitant:

The national park at Borre is the first national park in Norway. The national park is its name, and this cannot be changed in retrospect. For those of us who have grown up with the national park, this will always be the name. (Gjengangeren 24 May 2006, author's translation)

The writer concluded by demanding a "full explanation of why somebody has decided that the stately meeting hall [storstue] at Borre is in need of a new name". In consequence of this, the park now has two names. Officially, it is Borreparken, while locally it is still the national park. At present, both names are found at the entrance to the park. The entanglements have been materialised in the shape of two contrasting signboards.

The second dispute created by the preservation plan was the projected clearing of a large number of trees in the park and along the beach. The numerous trees that dominate 
the park are a beautiful sight and important landscape elements. The archaeologists who had been involved in the development of the plan pointed out, however, that the mounds originally had been placed to be seen very clearly from the sea and to announce the presence of powerful chieftains at Borre. The present-day picturesque landscape with the large mounds partly hidden by trees and lush greenery was not considered historically correct. A large number of trees needed to be cleared away to re-create more of the original landscape (Helhetsplan for Borreparken 2007-2015: 22-23).

This was not compatible with the perspectives of the local inhabitants and regular users of the area. To them, the trees and the forest were an important part of the attraction of the area. They did not want the trees removed. Moreover, they also reacted to the idea that outsiders had the power and the right to decide what the park should look like. When the plan was made public, the locals stressed that this was their forest, their beach and their recreational area. They pointed out how the beach and park were sites of celebrations on Constitution Day and Midsummer Eve, the scene of picnics and excursions in summer, and a favourite route for walks, for walking dogs and meeting friends and family throughout the year (Gjengangeren 10 November 2007). Chopping down the trees and laying the area open to the sea would change all this and deprive it of qualities that were experienced as essential.

The campaign against the clearing continued well into 2008 when the local branch of Friends of the Earth Norway invited people to defend the trees and the numerous threatened species that had been identified there. On a Sunday in March, locals marched eagerly to the park with slogans and ribbons to tie around the trees they wanted to save (Gjengangeren 3 March 2008). The will to preserve the forest was "deeply rooted", according to one local newspaper (Tønsbergs blad 3 March 2008). However, the campaign against the clearing project did not mean that the locals failed to acknowledge the great importance of the park as heritage. Neither was it a matter of social values being at odds with the values of professional and scientific heritage management (Jones 2017). Quite to the contrary, two leaders of the local initiative argued:

We are very much aware of the great historical importance of the mounds at Borre, also in a European context. This is why we sincerely wish the area to be taken care of and attended to for the best for the site itself and for living people in the present. The park is our stately meeting hall [storstue], our identity and our pride. (Gjengangeren 10 November 2007, author's translation)

The argument shows that the locals had internalised values from professional heritage work, stressing the historical and international aspects of the burial field at Borre. Rather, the dispute was about ownership: Who had the right to decide what the park 
should look like? It was also a dispute about what kind of heritage the park represented. One argument was that the trees should be preserved "for future generations" while the spokesmen in the quoted excerpt above stressed their importance to "living people in the present". The priorities of archaeologists and heritage professionals, on the other hand, were far less regarded. Their concern with how the area had once looked mattered less to the locals than the way it looked now, to them, and the way they wanted to leave it for the future.

When the entanglements that have been presented here are considered separately, we can see that they have different causes as well as different solutions. Some emerged from conflicting interests, some from different interpretations, some were due to political ideology and agency, and some concerned the authority of ownership. Moreover, some of these entanglements represented no real practical problems at all, some could be solved by negotiations and some continued as conflicts. In real life, however, things are more complex because the entanglements are entangled with each other. This is because they all take place in a restricted space, in this case the small community of Borre. They also often involve the same people, in different groupings. Many things are taking place on the same site, at times overlapping, sometimes existing side by side and on other occasions in conflict with each other.

Heritage is not simply carved out and set aside and safely protected once the struggle to preserve it has been won. The relation between heritage and everyday life is a muddled affair, and the line between them is porous and oscillating. My main point is that this is the normal and continuous state. Single issues or entanglements may be solved, but new ones will always appear. The muddle is part of the heritage field, one of the conditions of possibility for heritage.

In contrast to expansion and intensification, entanglements do not in themselves enhance heritage, neither in scope nor in meaning. Entanglements between heritage uses and values on the one hand, and other more mundane needs on the other, may even represent serious challenges, for instance when it comes to the practical use of a specific geographic area. Entanglements are nonetheless an important dimension of the "intrusive" power of heritage because entanglements, even more than the other two processes, serve to integrate heritage into local life and activities, weaving it together with issues of everyday life. Entanglements also involve a larger number of persons operating outside the sphere of heritage professionals or people with special interests in heritage. Again, these agents may have interests that do not agree with or may even exist in contradiction to heritage preservation. For just such reasons, their engagement and concerns are significant elements in making heritage part of the social texture of the political landscape and the cultural repertoire. Entanglements make heritage socially real outside its own limited sphere. 


\section{Conclusion: Heritage as an Invasive Force}

Although heritage often entails intrinsic vulnerability and the appeal for care and protection (Harrison 2013: 7), it is a powerful cultural and political force in its own right, with a strong potential for expansion and even for colonisation of its environments. Heritage research is permeated by such paradoxes that arise from the fact that heritage can be seen as highly effective meaning-making machinery that naturalises present-day values by making them materialise out of the past. Current heritage research generally agrees upon the constructed nature of heritage as created by discourses and practices in the present. Objects and items from the past - material or immaterial - are singled out, selected and ascribed value in the present (cf., e.g., Eriksen 1997; Kirshenblatt-Gimblett 1998; Smith 2006; Bendix \& Hafstein 2009). The process implies the construction of a metacultural level of meaning and results in a culture of culture (Hafstein 2009). Heritage is more or less by definition described as vulnerable and threatened by destruction (Klein 1997: 19; Harrison 2013: 7). As pointed out by Owe Ronström (2008: 87), it often comes with an intrinsic moral obligation: heritage must be protected and preserved. By implication, these understandings also present heritage as something select, exclusive and rare, as well as frail and set off from everyday life and practices. Heritage is not to be treated roughly. It deserves respect, and even if it is "visitable" (Macdonald 2013: 18), it exists at some conceptual distance from mundane life. Productive as such perspectives have been, they more or less fail to explicate another, equally important dimension of heritage: its immense cultural power, the social energy or vitality that is intrinsic to heritage in the contemporary world.

This articlehas argued that rather thanbeingweakor frail, heritagehas agreatcapacity to invade and colonise other aspects of life. It can redefine meaning and structure social networks and institutions in new ways. Rather than being rare and exclusive, heritage can expand and incorporate ever more elements that are then appropriated by the heritage sphere. My point is not to critique this, but to show how it happens empirically. I have used the triad of concepts - expansion, intensification and entanglement - to do so. By attending to these processes, heritage researchers improve the understanding of heritage and heritage production and explicate what Peter Jan Margry, among others, has called "heritagisation" (Margry 2011). This transformation process is often thought of as coming to an end when a heritage action has been taken, when the building, object or cultural expression in question has been protected or has gained formal status as heritage. The present article argues, however, that heritage processes continue after such goals have been achieved. They continue to operate, perhaps with even greater power and success. The case study examined here demonstrates that these processes and their agents are not external to heritage, but intrinsic to it. What creates ever more heritage and sustains heritagisation is heritage itself. 


\section{References}

\section{Literature}

Bendix, Regina \& Valdimar Tr. Hafstein 2009: Culture and Property: An Introduction. Ethnologia Europaea 39(2): 5-10. DOI: https://doi.org/10.16995/ee.1049

Bowman, Marion, Dirk Johannsen \& Ane Ohrvik 2020: Reframing Pilgrimage in Northern Europe: Introduction to the Special Issue. Numen 67(5-6): 439-452. DOI: https://doi.org/10. 1163/15685276-12341597

Brøgger, A.W. 1916: Borrefundet og Vestfoldkongernes graver. Videnskabsselskapets Skrifter 1. Kristiania: J. Dybwad.

Eriksen, Anne 1997: Minner fra den evige stad: Skandinaver i Roma 1850-1900. Oslo: Pax forlag.

Eriksen, Anne 2019: Vikinger, veibygging og verdensarv: Borrehaugene i Vestfold og kulturarvens konsekvenser. In: Camilla Asplund Ingemark, Carina Johansson \& Oscar Pripp (eds.), Former som formar: Musik, kulturarv, öar. Festskrift till Owe Ronström. Uppsala: Uppsala universitet, 145-158.

Flores, Jodi Reeves \& Roeland Paardekooper (eds.) 2014: Experiments Past: Histories of Experimental Archaeology. Leiden: Leiden Sidestone Press.

Gansum, Terje \& Terje Østigård 2009: Vikingtiden på Borre: Hvordan har fortiden blitt brukt og formidlet? In: Samuel Edquist, Lars Hermanson \& Stefan Johansson (ed.), Tankar om ursprung. Stockholm: Statens historiska museum, 249-268.

Goffman, Erwin 1974: Frame Analysis: An Essay on the Organization of Experience. Cambridge: Cambridge University Press.

Guttormsen, Torgrim Sneve 2014: Bruken av Borreparken i regionale kulturarvs-strategier i Vestfold. Viking, arkeologisk årbok 77: 159-182.

Hafstein, Valdimar Tr. 2009: Collectivity by Culture Squared: Cultural Heritage in Nordic Spaces. Arv 65: 11-24.

Harrison, Rodney 2013: Heritage: Critical Approaches. London: Routledge.

Irwin-Zarecka, Iwona 1994: Frames of Remembrance: The Dynamics of Collective Memory. New Brunswick: Transaction Publ.

Jones, Siân 2017: Wrestling with the Social Value of Heritage: Problems, Dilemmas and Opportunities. Journal of Community Archaeology \& Heritage 4(1): 21-37. DOI: https://doi.org/10.1 080/20518196.2016.1193996

Kirshenblatt-Gimblett, Barbara 1998: Destination Culture: Tourism, Museums, and Heritage. Berkeley: University of California Press.

Klein, Barbro 1997: Tillhörighet och utanförskap: Om kulturarvspolitik och folklivsforskning i en multietnisk värld. Rig 1-2: 15-32.

Krag, Claus 1991: Ynglingatal og ynglingesaga: En studie i historiske kilder. Oslo: Universitetsforlaget. Macdonald, Sharon 2013: Memorylands: Heritage and Identity in Europe Today. London: Routledge. DOI: https://doi.org/10.4324/9780203553336 
Margry, Peter Jan 2011: Memorializing a Controversial Politician: The "Heritagization" of a Materialized Vox Populi. In: Peter Jan Margry \& Cristina Sánchez-Carretero (eds.), Grassroots Memorials: The Politics of Memorializing Traumatic Death. New York: Berghahn, 319-345.

Meyer, Birgit \& Mattijs Van de Port (eds.) 2018: Sense and Essence: Heritage and the Cultural Production of the Real. New York: Berghahn Books. DOI: https://doi.org/10.2307/j.ctvw04hqq

Myhre, Bjørn 2003: Borregravfeltet som historisk arena. Viking, arkeologisk årbok 66: 49-77.

Myhre, Bjørn 2015: Før Viken ble Norge: Borregravfeltet som religiøs og politisk arena. Norske Oldfunn 31.

Myhre, Bjørn \& Terje Gansum 2003: Skipshaugen 900 e.Kr.: Borrefunnet 1852-2002. Vestfold fylkeskommune: Midgard historisk senter.

Myhre, Lise Nordenborg 1995: Fortida som propaganda: Arkeologi og nazisme, en faglig okkupasjon. Fra Haug ok Heiðni, 13-20.

Renes, Johannes 2015: Layered Landscapes: A Problematic Theme in Historic Landscape Research. In: Jan Kolen, Hans Renes \& Rita Hermans (eds.), Landscape Biographies. Amsterdam: Amsterdam University Press. DOI: https://doi.org/10.1515/9789048517800-019

Ronström, Owe 2008: Kulturarvspolitik: Visby, från sliten småstad till medeltidsikon. Stockholm: Carlssons.

Smith, Laurajane 2006: Uses of Heritage. London \& New York: Routledge. DOI: https://doi. org/10.4324/9780203602263

Smith, Laurajane (ed.) 2006: Cultural Heritage: Critical Concepts in Media and Cultural Studies. New York: Routledge.

Smith, Laurajane 2015: Intangible Heritage: A Challenge to the Authorised Heritage Discourse? Revista d'Etnologia de Catalunya 40: 133-142.

Smith, Laurajane \& Emma Waterton 2009: Heritage, Communities and Archaeology. London: Duckworth Publishing.

Waterton, Emma 2019: More-than-representational Landscapes. In: Peter Howard \& Brian Graham (eds.), Routledge Companion to Landscape Studies. London: Routledge, 91-101. DOI: https://doi. org/10.4324/9781315195063-7

Waterton, Emma \& Steve Watson 2014: The Semiotics of Heritage Tourism. Bristol: Channel View Publications. DOI: https://doi.org/10.21832/9781845414221

Winther, Birgitte 2019: Ideen om det norske folk: Vidkun Quislings taler på Nasjonal Samlings pinsestevner i Borreparken i 1941, 1962 og 1943. Master's degree thesis in History of Ideas, University of Oslo.

\section{Internet Sources}

Aftenposten, p. 2, 26 March 2019, https://www.aftenposten.no/.

Borre Historielag (amateur history association), https://www.borre-historielag.no (accessed November 18, 2020). 
Borre Vikinglag, http://www.borrevikinglag.com/ (accessed November 17, 2020); http://www. borrevikinglag.com/?page_id=41, http://borrefylkingen.net/om-oss/ (accessed October 18, 2021).

Gjengangeren, p. 7, 24 May 2006; p. 5, 10 November 2007; p. 2, 3 March 2008; p. 3, 21 August 2012; p. 1, 12 July 2018, https://www.gjengangeren.no/ (accessed November 17, 2020).

Helhetsplan for Borreparken 2007-2015. Digital document, 4. Skjøtselsplan (yumpu.com) (accessed October 18, 2021).

Lund \& Slaatto Architects, https://www.Isa.no (accessed November 24, 2020).

Midgard Vikingcenter, https://vestfoldmuseene.no/en/midgard-viking-centre/ (accessed November 17, 2020); https://vestfoldmuseene.no/kalender/morke-skyer-over-borre/ (accessed October 18 2021).

Pilegrimsleden, https://pilegrimsleden.no/turforslag/tonsberg-til-asgardstrand-eller-borre (accessed November 18, 2020).

Steinbrygga, http://steinbrygga.no (accessed November 18, 2020).

Tønsbergs Blad, p. 7, 3 March 2008; p. 43, 23 April 2015, https://www.tb.no.

Unesco, Tentative Lists, http://whc.unesco.org/en/tentativelists/5577/ (accessed October 18, 2021).

Unesco, World Heritage List, http://whc.unesco.org (accessed October 18, 2021).

\section{Fieldwork and Unpublished Sources}

Author's fieldwork notebook, July 2018, July and August 2019, July 2020.

Brøgger, A.W. 1932: Rikshagen: Tale på Borre 19. juli 1932. Unpublished manuscript, filed in the Museum of Cultural History, University of Oslo.

Interviews: Terje Gansum, July 6, 2018, and August 13, 2019.

Anne Eriksen is a professor of cultural history (folklore studies) at IKOS, University of Oslo and an adjunct professor of cultural Studies at AHKR, University of Bergen. She has published widely on the history of knowledge, heritage, museums and the uses of the past. A recent publication is Vikinger, veibygging og verdensarv [The Vikings, roadbuilding and world heritage], in Former som formar (Uppsala 2019). 